\begin{tabular}{|c|c|c|}
\hline 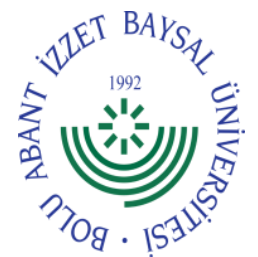 & $\begin{array}{l}\text { International Journal of Agriculture and Wildlife } \\
\qquad \text { Science } \\
\text { http://dergipark.org.tr/jiaws }\end{array}$ & 每 \\
\hline
\end{tabular}

Research Article

\title{
Determination of Some Growth Parameters of Different Grass Species and Varieties in the Soilless Medium
}

\author{
Muhammet Karaşahin
}

Çumra School of Applied Sciences, Selcuk University, Konya, Turkey

Received: 09.09.2020 Accepted: 29.11.2020

\section{Keywords:}

Grass species and varieties, hydroponic, roll sod
${ }^{*}$ Corresponding author mkarasahin@selcuk.edu.tr
Abstract. This study was conducted in order to determine some growth parameters of different grass species and varieties in the soilless medium. According to the research results, the highest green plant yields were obtained from S7 and S8 pure species and varieties. The highest dry matter rate values were obtained from S6, while the highest plant height, root and leaf blade length values were obtained from S2. The earliest emergence and covering speed values were obtained from pure species and varieties of S1, S7, S8, and S9. The best overall appearance values were obtained from S7, while the highest shoot diameter values were obtained from S1. The highest tiller number values were obtained from S8, while the highest leaf blade width values were obtained from S1. The highest index values, on the other hand, were obtained from S5. When the results of the research are evaluated based on the highest overall appearance values, S7 (Lolium perenne L.) is in the advisable quality in terms of the production of the soilless roll sod.

\section{Farklı Çim Tür ve Çeşitlerinin Topraksız Ortamda Bazı Gelişim Parametrelerinin Belirlenmesi}

\section{Anahtar kelimeler:}

Çim tür ve çeşitleri, hidroponik, rulo çim
Özet. Bu çalışma farklı çim tür ve çeşitlerinin topraksız ortamda bazı gelişim parametrelerinin belirlenmesi amacıyla yapılmıştır. Araştırma sonuçlara göre en yüksek yeşil bitki verimleri S7 ve S8 saf tür ve çeşitlerinden elde edilmiştir. En yüksek kuru madde oranı değerleri S6'dan elde edilirken, en yüksek bitki boyu, kök ve yaprak ayası uzunluğu değerleri S2'den elde edilmiştir. En erken çıkış ve kaplama hızı değerleri S1, S7, S8 ve S9 saf tür ve çeşitlerinden elde edilmiştir. En iyi genel görünüm değerleri S7'den elde edilirken, en yüksek sürgün çapı değerleri ise S1'den elde edilmiştir. En yüksek kardeş sayısı değerleri S8'den elde edilirken, en yüksek yaprak ayası genişliği değerleri S1'den elde edilmiştir. En yüksek indeks değerleri ise S5'den elde edilmiştir. Araştırma sonuçları en yüksek genel görünüm değerleri dikkate alınarak değerlendirildiğinde S7 (çok yıllık çim (Lolium perenne L.)) topraksız rulo çim üretiminde tavsiye edilebilir niteliktedir. 


\section{INTRODUCTION}

Grass plants are indispensable when it is necessary to create a physically and spiritually healthy environment for people who have to live in cities (Özcan, 2007). Grass areas absorb the sun rays during the day, while at night they positively affect the environment by not returning the radiation they collect during the day. The fact that green field plants lose water through sweating leads to a decrease in temperature up to $5{ }^{\circ} \mathrm{C}$ in the summer ambient temperature; on a well-established $1 \mathrm{~m}^{2}$ grass surface, approximately 4000 grass plants function as an air conditioner due to their energy absorption properties. When the same surface is covered with concrete, this temperature difference may be $20-25^{\circ} \mathrm{C}$ more (Uzun, 1989). Grass plants are annual and perennial, herbaceous, or woody plants that comprise 600 genera and more than 9000 species which constitute an important part of the natural vegetation, and that are members of one of the largest plant families, the family Poaceae (Gramineae). The Poaceae (Gramineae) species and varieties used in urban green areas, recreation areas and sports areas are called by the generic name 'grass' (Karagüzel, 2007). Grass plants reduce air temperature by absorbing the sun rays, remove dust from the air, prevent erosion, and give people peace of mind. The installation of a healthy and high-quality grass field plant is very difficult and requires technical knowledge. Many applications, such as soil preparation, rough grading, fine grading, seed selection, and the preparation of the mixture, sowing time, sowing depth and density, preparation of grass cover and laying and compaction of it, and irrigation after sowing, must be carried out in accordance with the technique.

The roll sod is a grass form created by cutting the grass with its roots from the land and wrapping it in rolls like a carpet and making it ready to be laid on another area. The grass used here is the grass that was previously planted in the soil and whose root development was ensured by mowing several times and caring. In order to create a healthy grass area, a time period such as 3-4 months in the production from seed is needed. Those who do not have sufficient technical knowledge and infrastructure, those who want to perform grass applications in hot summer months when planting grass is risky, and those who want green fields within a short time prefer to use ready-roll sod. In ready-roll sod cultivation, planting, maintenance, and processes of carrying and transportation of heavy grass rolls are factors that increase the cost compared to the seeded grass. In the openfield roll sod production, at least 6 , average 18 months are needed for the roots to completely cover the soil and hold the soil without spilling when harvested (Özad, 2010). Although in the production of roll bermudagrass (Cynodon magenissii), Japanese grass (Zoysia japonica), and centipedegrass (Eremochloa ophiuroides) produced in field conditions, 3-12, 12-18 and 12-15 months are needed, respectively, the same species can become available for sale with this technique in 6,15 and 10 weeks, respectively. To be able to reduce shipping costs for long distances, roll sods with soil can be loaded as washed roll-sod after washing in the washing machine; however, this requires additional investment and labor (Bruce, 2000). Washed roll sod is obtained by separating the harvested roll sod from the soil by means of water jets while it is proceeding on the conveyor belt (Turgeon, 1977). Since the soil is not carried in the washed roll sod, it is quite light and therefore the loading and shipping costs are low. The cost of washed roll sod is $50 \%$ more than the cost of roll sod. Because of this high cost, they are preferred only in necessary cases. Certain varieties of grass, especially those with rhizome structure, are preferred in the production of washed roll sod to ensure the grass not to disperse from each other. Whereas the rhizomes of bermudagrass, which are mostly used in the production of washed roll sod, can be shipped after washing, drying, and treating with drugs such as nematocytes, fungicides, and insecticides after harvesting, these operations are not needed in the production of the soilless roll sod.

In washed roll sod, grasses grown in an environment with soil are cleaned from the soil by washing after being harvested, while soilless roll sod production is a grass production performed on impermeable sheets using various substrate materials other than the soil. Since soilless roll sod production is done by using biodegradable substrate material on impermeable sheets such as plastic, grass roots are not cut during harvest. Thus, grass roots are integrated with the soil in a shorter time in the area where it is applied. Since soil is not used in the production, the soil laying costs are eliminated. In the production of soilless roll sod, artificial organic fiber materials can be used as substrate materials (Karaşahin, 2020). The production of soilless roll sod can be performed faster than the traditional roll sod production. In addition, while the plants go into shock because the roots are cut and harvested in the roll sod production carried out in the field conditions, this negativity is not experienced in the soilless roll sod production; thus, this provides significant increases in quality. There is a 24 times difference between the weight of the roll sod produced in the soil and the weight of the soilless roll sod. Thanks to all these, a serious production advantage is able to be achieved in the production of soilless roll sod compared to the production of roll sod performed in the field conditions. 
One of the important problems encountered in the installation of a grass area is the species and variety of poaceae to be selected. A successful grass plant selection is related to knowing how to use the grass, where to grow it, what is the acceptable level of persistence and appearance. Because each grass species has its own unique characteristics, strengths, and weaknesses, it is necessary to know these characteristics well in terms of special conditions (Harivandi et al., 1984). The determination of the quality of grass areas is carried out in two different aspects. The first is the individual quality characteristics of the plants that make up the grass texture and are mainly consisted of poaceae. Some of these individual quality characteristics are color, growth and development speed, growth form, root development, and showing resistance against dense and bottom forms, crushing and traffic effect, compact forms and pressing, drought and temperature, disease, and pests. The second is the general characteristics of green field vegetation, which these plants create by growing and developing together, such as uniformity, texture, flatness, density (area covered with plant), and dry grass yield (Avcioğlu and Geren, 2012; Balekoğlu, 2015).

In this study, it was aimed to determine the species and varieties of grass appropriate for soilless roll sod production.

\section{MATERIAL AND METHOD}

The research was carried out in the hydroponics production field at Selcuk University, Cumra School of Applied Sciences (Figure 1). $33 \times 11.5 \mathrm{~cm}$ aluminum frames were used as the cultivation setting (Figure 2).

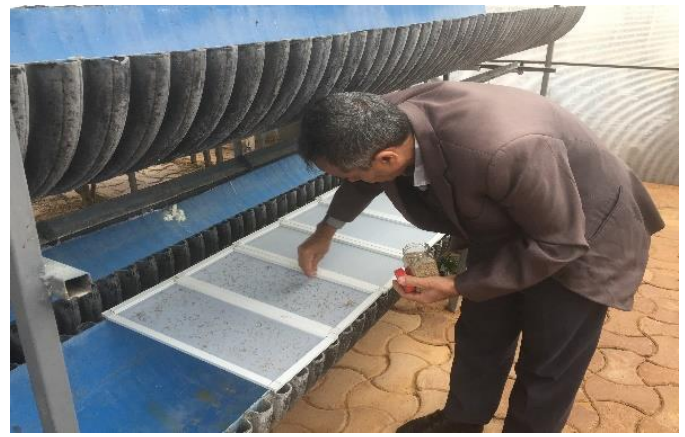

Figure 1. Hydroponics production field. Şekil 1. Hidroponik üretim alanı.

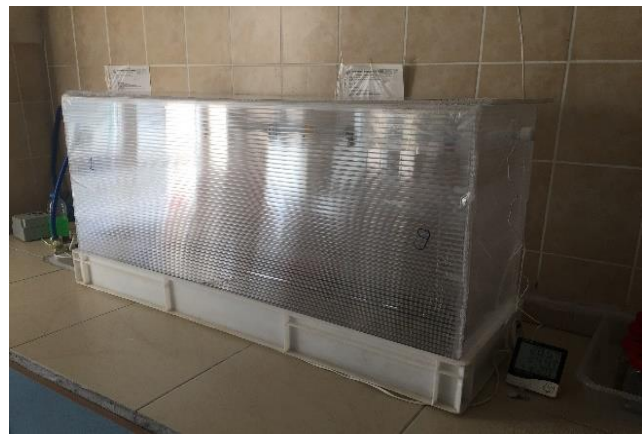

Figure 2. Cultivation setting.

Şekil 2. Yetiştirme düzeneği.

In the study, $50 \mathrm{~g} \mathrm{~m}^{-2}$ was applied as plant density, $20^{\circ} \mathrm{C}$ as ambient temperature, control as growing medium and fertilizer source, cotton fiber as the substrate material, sprinkler as irrigation method $\left(20 \mathrm{sec}^{-1} 6 \mathrm{~h}^{-1}\right)$, and 15 days as cultivation period. In the irrigation system, the city water supply network was used as the water source (Table 1).

Table 1. Properties of the irrigation water.

Çizelge 1. Sulama suyu özellikleri.

\begin{tabular}{|c|c|c|c|}
\hline \multicolumn{2}{|c|}{ Specifications $\left(\mathrm{mg} \mathrm{l}^{-1}\right)$} & \multicolumn{2}{|c|}{ Specifications $\left(\mathrm{mg} \mathrm{l}^{-1}\right)$} \\
\hline $\mathrm{pH}$ & 7.19 & $\mathrm{Zn}$ & 0.94 \\
\hline $\mathrm{EC}\left(\mathrm{mS} \mathrm{cm}^{-1}\right)$ & 0.615 & $P$ & 0.20 \\
\hline $\mathrm{NO}_{3}\left(\mathrm{mg} \mathrm{l}^{-1}\right)$ & 3.22 & $\mathrm{~K}$ & 0.03 \\
\hline $\mathrm{Ca}\left(\mathrm{mg} \mathrm{l}^{-1}\right)$ & 150.12 & B & 0.13 \\
\hline $\mathrm{Mg}\left(\mathrm{mg} \mathrm{I}^{-1}\right)$ & 10.7 & $\mathrm{Mn}$ & 0.02 \\
\hline $\mathrm{Na}\left(\mathrm{mg} \mathrm{|}^{-1}\right)$ & 2.93 & $\mathrm{Cu}$ & 0.02 \\
\hline
\end{tabular}

In the research, the common bent (Agrostis tenuis Sibth.) H. Bent (S1), creeping bentgrass (Agrostis stolonifera L.) Lexington (S2), tall fescue (Festuca arundinacea Schreb.) Titanium LS (S3), creeping red fescue (Festuca rubra subsp. L. rubra) Navigator II (S4), Chewing's fescue (Festuca rubra subsp. L. commutata) Radar (S5), sheep's fescue (Festuca ovina L.) Chariot (S6), perennial ryegrass (Lolium perenne L.) Apple GL (S7), Kentucky bluegrass (Poa pratensis $\mathrm{L}$.) Volt (S8), and Bermuda grass (Cynodon dactylon L.) Gobi (S9) were used as plant materials. In order to determine the species and varieties of pure grass appropriate for the production of soilless roll sod, green 
plant yield $\left(\mathrm{g} \mathrm{m}^{-2}\right)$, dry matter rate (\%), dry grass yield $\left(\mathrm{g} \mathrm{m}^{-2}\right)$, plant height $(\mathrm{mm})$, emergence speed (day), covering speed (day), root length $(\mathrm{cm})$, overall appearance (1-9), shoot diameter $(\mathrm{mm})$, tiller number ( $\mathrm{unit}_{\mathrm{cm}} \mathrm{c}^{-1}$ ), leaf blade length $(\mathrm{cm})$, leaf blade width $(\mathrm{mm})$ and the index value (leaf blade length/leaf blade width) were examined (Beard, 1973; Avcıoğlu, 1997; Borawska-Jarmulowicz et al., 2017).

The trials were conducted as three replications according to the randomized plots experimental design. The results were subjected to the variance analysis, and differences were determined by using the $\mathrm{F}$ test. The average values of the processes whose differences were determined were grouped according to the "HSD" significance test (JMP, 2007).

\section{RESULTS AND DISCUSSION}

\section{Growth Parameters Obtained from Different Pure Species and Varieties}

Among the different pure species and varieties, the highest green plant yield (607.10 and 507.85) was obtained from S8 and S7, respectively, and they took place in the same statistical group (a) $(P<0.01)$. The lowest value (184.45), on the other hand, was obtained from S3. The highest values of dry matter (13.45) were obtained from S6, while the lowest values were obtained from S8, S9, and S7 (4.4, 5.1, and 5.6, respectively; $\mathrm{p}<0.01)$, and they were in the same statistical group (e). Here, the decrease in dry matter rates as green plant yields increased attracted the attention. Therefore, it was observed that there was no statistical difference between pure species and varieties in terms of dry grass yields (Table 2). The highest plant height and root length values were obtained from S2 (9.3 and 4.3, respectively). The lowest plant height value (1.9) was obtained from S3, while the lowest root length values were obtained from S9, S8, and S3 $(0.4,0.5$, and 0.6 , respectively), and they took place in the same statistical group (c) $(P<0.01)$.

The earliest emergence (5) and covering speed values were obtained from S1, S7, S8, and S9, and they took place in the same statistical group (c) $(P<0.01)$. The latest emergence and covering speed values were obtained from S3 and S6 (7.11 and 7.11, respectively), and they were in the same statistical group (a) $(P<0.01$, Table 2$)$.

Table 2. Green plant yield, dry matter rate, dry grass yield, plant height, emergence, covering speed, and root length values of different pure species and varieties.

Çizelge 1. Farklı saf tür ve çeşitlerin yeşil bitki verimi, kuru madde oranı, kuru ot verimi, bitki boyu, çıkış ve kaplama hızı ile kök uzunluğu değerleri.

\begin{tabular}{|c|c|c|c|c|c|c|c|c|}
\hline \multicolumn{2}{|c|}{ Applications } & $\begin{array}{l}\text { Green Plant } \\
\text { Yield } \\
\left(\mathrm{g} \mathrm{m}^{-2}\right)\end{array}$ & $\begin{array}{l}\text { Dry Matter } \\
\text { Rate } \\
\text { (\%) }\end{array}$ & $\begin{array}{l}\text { Dry Grass } \\
\text { Yield } \\
\left(\mathrm{g} \mathrm{m}^{-2}\right)\end{array}$ & $\begin{array}{l}\text { Plant } \\
\text { Height } \\
\text { (cm) }\end{array}$ & $\begin{array}{l}\text { Emergence } \\
\text { Speed } \\
\text { (day) }\end{array}$ & $\begin{array}{l}\text { Covering } \\
\text { Speed } \\
\text { (day) }\end{array}$ & $\begin{array}{l}\text { Root } \\
\text { Length } \\
\text { (cm) }\end{array}$ \\
\hline & S1 & $377.59 \mathrm{bc}$ & $8.8 \mathrm{~cd}$ & 33.20 & $8.6 a b$ & $5 \mathrm{c}$ & $7 \mathrm{c}$ & $3.5 \mathrm{~b}$ \\
\hline Pure & S2 & 344.65 c & $9.8 \mathrm{bc}$ & 33.99 & $9.3 \mathrm{a}$ & $6 \mathrm{~b}$ & $8 b$ & $4.3 \mathrm{a}$ \\
\hline \multirow{2}{*}{ Species } & S3 & 184.45 e & $8.5 d$ & 15.81 & $1.9 \mathrm{f}$ & $7 a$ & $11 \mathrm{a}$ & $0.6 \mathrm{c}$ \\
\hline & S4 & $373.11 \mathrm{bc}$ & $8.4 d$ & 31.62 & $6.0 \mathrm{bcd}$ & $6 \mathrm{~b}$ & $8 b$ & $3.0 \mathrm{~b}$ \\
\hline and & S5 & 329.37 c & $10.57 b$ & 34.78 & $6.6 a b c$ & $6 \mathrm{~b}$ & $8 \mathrm{~b}$ & $3.6 \mathrm{ab}$ \\
\hline \multirow[t]{4}{*}{ Varieties } & S6 & $251.11 \mathrm{~d}$ & $13.45 \mathrm{a}$ & 33.72 & $5.6 \mathrm{~b}-\mathrm{e}$ & $7 a$ & $11 \mathrm{a}$ & $3.0 \mathrm{~b}$ \\
\hline & S7 & $577.85 a$ & $5.6 \mathrm{e}$ & 32.67 & $4.8 c-f$ & $5 c$ & $7 c$ & $3.3 \mathrm{~b}$ \\
\hline & S8 & $607.10 \mathrm{a}$ & $4.4 \mathrm{e}$ & 26.87 & 3.0 def & $5 c$ & $7 c$ & $0.5 \mathrm{c}$ \\
\hline & S9 & $402.89 \mathrm{~b}$ & $5.1 \mathrm{e}$ & 20.81 & 2.7 ef & $5 c$ & $7 \mathrm{c}$ & $0.4 \mathrm{c}$ \\
\hline HSD & & $40.84^{\star \star}$ & $0.008^{* *}$ & Ns & $2.2^{* *}$ & $0.001^{* *}$ & $0.38^{* *}$ & $0.58^{* \star}$ \\
\hline
\end{tabular}

HSD; Honesty significant difference, $*$; $P<0.05, * * ; P<0.01, N s ;$ Not significant.

The highest overall appearance values (10) were obtained from S7, while the lowest values (2) were obtained from S2 $(P<0.01)$. The highest shoot diameter and leaf blade width values were obtained from S1 $(0.51$ and 6.3 , respectively; $P<0.01$ ). While the lowest leaf blade width values (1.2) were obtained from $S 3$, the lowest shoot diameter values (0.25) were obtained from S7 and S9, and they took place in the same statistical group (d) $(P<0.01)$. The highest tiller number values (3600) were obtained from $S 8$, while the lowest values (833) were obtained from S1 $(P<0.01)$. It was assumed that the reason for these low tiller number values to be obtained from $\mathrm{S} 1$ is due to seed thickness. The highest leaf blade length values (7.3) were obtained from S2 while the lowest values (1.2) were obtained from S3 $(P<0.01)$. It was thought that the reason why the lowest values were obtained from S3 was that it had the lowest size thickness. While the highest index values (123.3) were obtained from S5, the lowest values $(30)$ were obtained from S3 $(P<0.01)$ (Table 3$)$. 
Table 3. Overall appearance, shoot diameter, tiller number, leaf blade length, leaf blade width, and index values of different pure species and varieties.

Çizelge 3. Farklı saf tür ve çeşitlerin genel görünüm, sürgün çapı, kardeş sayısı, yaprak ayası uzunluğu, yaprak ayası genişliği ve indeks değerleri.

\begin{tabular}{|c|c|c|c|c|c|c|c|}
\hline \multicolumn{2}{|c|}{ Applications } & $\begin{array}{l}\text { Overall } \\
\text { Appearance } \\
(1-9)\end{array}$ & $\begin{array}{l}\text { Shoot } \\
\text { Diameter } \\
(\mathrm{mm})\end{array}$ & $\begin{array}{l}\text { Tiller } \\
\text { Number } \\
\left(\text { Number } \mathbf{d m}^{-2}\right)\end{array}$ & $\begin{array}{l}\text { Leaf Blade } \\
\text { Length } \\
(\mathrm{cm})\end{array}$ & $\begin{array}{l}\text { Leaf Blade } \\
\text { Width } \\
(\mathrm{mm})\end{array}$ & $\begin{array}{l}\text { Index } \\
\text { Values }\end{array}$ \\
\hline \multirow{3}{*}{ Pure } & S1 & $9 \mathrm{~b}$ & $0.51 \mathrm{a}$ & $833 d$ & $6.3 \mathrm{ab}$ & $1.06 \mathrm{a}$ & $59.6 \mathrm{de}$ \\
\hline & S2 & $8 c$ & $0.40 \mathrm{~b}$ & 622 de & $7.3 \mathrm{a}$ & $0.70 \mathrm{~b}$ & $104.7 \mathrm{ab}$ \\
\hline & S3 & $2 \mathrm{f}$ & $0.30 \mathrm{c}$ & $122 \mathrm{f}$ & $1.2 \mathrm{~d}$ & 0.40 def & $30.0 \mathrm{e}$ \\
\hline Species & S4 & $8 c$ & $0.28 \mathrm{c}$ & 1089 c & $4.3 \mathrm{bc}$ & $0.46 \mathrm{de}$ & $93.3 \mathrm{abc}$ \\
\hline \multirow{2}{*}{ and } & S5 & $7 \mathrm{~d}$ & $0.3 \mathrm{c}$ & $644 \mathrm{de}$ & $6.1 \mathrm{ab}$ & $0.50 \mathrm{~cd}$ & 123.3 a \\
\hline & S6 & $6 \mathrm{e}$ & $0.4 \mathrm{~b}$ & $467 \mathrm{e}$ & $4.1 \mathrm{bc}$ & $0.60 \mathrm{bc}$ & $69.4 \mathrm{~cd}$ \\
\hline \multirow[t]{3}{*}{ Varieties } & S7 & $10 \mathrm{a}$ & $0.25 \mathrm{~d}$ & 1089 c & $3.9 \mathrm{bc}$ & 0.35 ef & $113.3 \mathrm{ab}$ \\
\hline & S8 & $7 \mathrm{~d}$ & $0.20 \mathrm{e}$ & 3600 a & $2.5 \mathrm{~cd}$ & $0.30 \mathrm{f}$ & $83.3 \mathrm{bcd}$ \\
\hline & S9 & $7 \mathrm{~d}$ & $0.25 \mathrm{~d}$ & $2822 b$ & $2.2 \mathrm{~cd}$ & 0.35 ef & $64.7 \mathrm{~cd}$ \\
\hline HSD & & $0,001^{* *}$ & $0.02^{* *}$ & $168.4^{\star \star}$ & $1.87^{\star \star}$ & $0.08^{* *}$ & $21.7^{\star \star}$ \\
\hline
\end{tabular}

HSD; Honesty significant difference, ${ }^{*} ; \mathrm{P}<0.05,{ }^{*} ; \mathrm{P}<0.01, \mathrm{Ns} ;$ Not significant.

Açıkgöz (1994), reported that in the most suitable conditions in the field context, Lolium perenne seeds germinated within 5-10 days, while the species of fescue germinated within 10-15 days. They also reported that while this period could extend to 20 days in bentgrass species, it could extend up to 30 days in bluegrass species. Whereas grass roots expend serious energy by going to deep in the production technique performed with soil, they use the majority of their energy on the production of green parts in the production technique of soilless roll sod. Therefore, the time required to be ready for sale is getting considerably shorter (Alagöz, 2016). In grass plants, the excessiveness of the number of shoots (density value) in the unit area is important in terms of preventing undesirable weeds, covering the area completely, and creating a green vegetation; the excessiveness of the number of shoots in the unit area is a desirable feature in grass areas. In stolon and rhizome plants, there should be more than 200 shoots in $1 \mathrm{dm}^{2}$ area in order to form a dense cover (Avcıoğlu, 1997). It has been reported that Lolium perenne is highly preferred in repairing damaged grass areas due to its ability to germinate fast and covering speed (Turgeon, 2002). Coarse-seeded species, such as fescue species and Lolium perenne seeds, germinate faster because they contain more endosperms. These species are more fortunate in terms of breaking the grass cover after germination (Demiroğlu et al., 2010).

In pure sowing, due to the similarity in their unique structure and characteristics, sowing of seeds and setting sowing amount and depth is easier than the mixture seeds. The condition of increasing some species and decreasing some other species as in mixture sowing does not occur. With species that can settle quickly, vegetation can be created in a shorter time. In goal-directed use, the single species is more appropriate (Altın et al., 2005).

In the study carried out by Kuşvuran (2009), with the aim of identifying grass species and mixtures suitable for Çukurova conditions and determining their performance, randall grass and bentgrass species, which were coolseason grass plant species, showed superiority to other species in terms of quality, color, and plant-covered area values. On the other hand, Lolium perenne, along with randall grass, showed superiority to other species in terms of vegetation height, green grass yield, and dry grass yield values, while it showed superiority along with creeping red fescue to other species in terms of germination time and covering speed values (Kuşvuran, 2009).

\section{CONCLUSION}

According to the research results, the highest green plant yields were obtained from pure species and varieties of S7 and S8. The highest dry matter rate values were obtained from S6, while the highest plant height, root and leaf blade length values were obtained from S2. The earliest emergence and covering speed values were obtained from pure species and varieties of S1, S7, S8 and S9. While the best overall appearance values were obtained from $\mathrm{S7}$, the highest shoot diameter values were obtained from S1. The highest tiller number values were obtained from S8, while the highest leaf blade width values were obtained from S1. The highest index values, on the other hand, were obtained from S5.

When the results of the research are evaluated based on the highest overall appearance values, it can be said that $\mathrm{S} 7$ (Lolium perenne L.) is in the advisable quality in terms of the production of the soilless roll sod. 
In future research to be conducted, it is seen that making comparative cost analyses by incorporating different cultivation times and land applications into the studies will be useful.

\section{CONFLICT OF INTEREST}

The author declare that there is no conflict of interest.

\section{DECLARATION OF AUTHOR CONTRIBUTION}

As an author, the planning, preparation, analysis of experiment and writing of the manuscript was done by me.

\section{ACKNOWLEDGMENT}

The author is thankful for the support extended by Selçuk University Scientific Research Projects (BAP). This research consists of a part of the project numbered 17401185 .

\section{REFERENCES}

Açıkgöz, E. (1994). Çim Alanlar Yapım ve Bakım Tekniği. Çevre Yayınları, Yayın No:4, Bursa.

Alagöz, M. (2016). Isparta ekolojik koşullarında bazı buğdaygil çim bitkileri ve karışımlarının yeşil alan performanslarının belirlenmesi. Yüksek Lisans Tezi, Süleyman Demirel Üniversitesi Fen Bilimleri Enstitüsü, Isparta.

Altın, M., Gökkuş, A., \& Koç, A. (2005). Çayır Mera Islahı. Tarım ve Köyişleri Bakanlığı, Çayır Mera ve Havza Geliştirme Daire Başkanlığı Yayınları, Ankara.

Avcıoğlu, R. (1997). Çim Tekniği, Yeşil Alanların Ekimi Dikimi ve Bakımı. Ege Üniversitesi Matbaası, Bornova-İzmir.

Avcıoğlu, R., \& Geren, H. (2012). Bazı sıcak iklim çim buğdaygillerinin akdeniz iklimindeki performansları üzerinde araştırmalar. Anadolu J. of A.A.R.I., 22(1), 1-17.

Balekoğlu, E. (2015). Farklı kamışsı yumak (Festuca arundinacea) çim çeşitlerinin akdeniz ekolojisine adaptasyon özellikleri üzerinde araştırmalar. Yüksek Lisans Tezi, Ege Üniversitesi Fen Bilimleri Enstitüsü, İzmir.

Beard, J. B. (1973). Turfgrass: Science and Culture, Prentice-Hall, Inc., Englewood Cliffs, New Jersey, USA.

Borawska-Jarmułowicz, B., Mastalerczuk, G., Gozdowski, D., Małuszyńska, E., \& Szydłowska, A. (2017). The sensitivity of Lolium perenne and Poa pratensis to salinity and drought during the seed germination and under different photoperiod conditions. Zemdirbyste-Agriculture, 104(1), 71-78 .

Bruce, F. S. (2000). Soilless sod use tied to economy, USGA Specs TurfGrass Trends January, 9, 9-12.

Demiroğlu, G., Soya, H., Avcıoğlu, R., \& Geren, H. (2010). Ege bölgesi sahil kuşağı koşullarında bazı yeni ingiliz çimi (Lolium perenne L.) çeşitlerinin yeşil alanlara uygunlukları üzerinde bir araştırma. Ege Üniversitesi Ziraat Fakültesi Dergisi, 47(1), 7178.

Harivandi, M. A., Davis, W., Gibeault, V. A., Henry, M., Dam, J. V., \& Wu, L. (1984). Factors in turfgrass irrigation. California Turfgrass Culture, 34(4), 17-24.

JMP. (2007). Statistic and Graphics Guide, Release 7, SAS Institute Inc, Cary, USA.

Karagüzel, O. (2007). Çim ve Yerörtücü Bitkiler Ders Notu. Akdeniz Üniversitesi, Ziraat Fakültesi Yayınları, Antalya.

Karaşahin, M. (2020). Topraksız rulo çim üretimi ve avantajları. HarmanTIME, 89, 94-96.

Kuşvuran, A. (2009). Çukurova koşullarına uygun çim tür ve karışımlarının belirlenmesi ve performanslarının saptanması. Doktora Tezi, Çukuova Üniversitesi, Fen Bilimleri Enstitüsü, Adana.

Özad, E. (2010). Organik atıklardan rulo çim yetiştirme ortamının hazırlanması. Yüksek Lisans Tezi, Sakarya Üniversitesi Fen Bilimleri Enstitüsü, Sakarya.

Özcan, S. (2007). Bazı çim bitkilerinin yetiştirilmesi üzerine farklı gübrelemenin ve arıtılmış atıksu ile sulamanın etkileri. Celal Bayar Üniversitesi Fen Bilimleri Dergisi, 3(1), 23-28.

Turgeon, A. J. (1977). Comparative advantages of soilless sod for kentucky blue grass. Rasen Grun-Flachen Begrunungen, 8(1), 13-15.

Turgeon, A. J. (2002). Turfgrass Management. 6th ed. Prentice Hall Inc., NJ. U.S.A 
Karaşahin, Determination of Some Growth Parameters of Different Grass Species and Varieties in the Soilless Medium

Uzun, G. (1989). Peyzaj Mimarlığında Çım Ve Sporlanları Yapımı. Çukurova Üniversitesi Ziraat Fakültesi Yayınları, Yayın No: 20, Adana. 